\title{
AN ANALYSIS OF THE DIFFERENCE BETWEEN INA-CBG REIMBURSEMENTAND MEDICAL COST FOR PATIENTS WITH CHRONIC RENAL DISEASE: AN EVIDENCE FROM KASIH IBU HOSPITAL, SURAKARTA
}

\author{
Mardhatillah',3), Didik Gunawan Tamtomo²), Bhisma Murti3) \\ ${ }^{1)}$ Kasih Ibu Hospital, Surakarta, Central Java \\ 2)Faculty of Medicine, Universitas Sebelas Maret \\ 3)Masters Program in Public Health, Universitas Sebelas Maret
}

\begin{abstract}
Background: INA-CBG is an abbreviation of Indonesia Case Base Groups which is an application that the hospital uses to make claims to the government. For health service payments under the Indonesian National Health Insurance (JKN) scheme, health-BPJS as the JKN implementer makes payments to the hospitals based on INA-CBG rates. However, this has not been effective because INA rates of CBG have the potential to cause loss to hospitals. This study aimed to estimate the difference between INA-CBG reimbursement and medical cost for patients with chronic renal disease in Kasih Ibu Hospital, Surakarta, and analyze factors affecting the difference.

Subjects and Method: This was a cross sectional study conducted at Kasih Ibu Hospital Surakarta, Central Java, in August to October 2017. With a total of 231 subjects sample which was selected by using proportional random sampling. The dependent variable was the difference between INA-CBG reimbursement and medical cost. The independent variables were length of stay, type of class, medical treatment/ surgery, ICU treatment, and medication use. The data were analyzed using amultiple linearregression.

Results: INA-CBG reimbursement (mean $=\mathrm{Rp}$ 6,120,000; $\mathrm{SD}=\mathrm{Rp} 2,330,000$ ) paid by BPJS Kesehatan was lower than actual hospital's medical care cost (mean= Rp 7,070,000; $\mathrm{SD}=\mathrm{Rp} 4,650,000$ ). Factors profitable for hospitals were medical treatments/ surgery $(b=0.032 ; p=0.552)$. Factors that inflicted financial loss were class 1 care $(b=-0.104 ; p=0.094)$, class 2 care $(b=-0.033 ; p=0.590)$ compared to class 3 care, length of stay $(b=-0.541 ; p<0.001)$, medication use in accordance with national formulation $(b=-0.183 ; p=0.008)$ and the use of ICU $(b=-0.045 ; p=0.543)$. Patients who upgraded the class type (mean $=R p$ 5,526,074; $\mathrm{SD}=\mathrm{Rp} 1,449,621)$ was higher than hospital's medical cost for class 2 (mean= Rp 3,933,767; $\mathrm{SD}=\mathrm{Rp} 1,887,900)$.

Conclusion: Mean of INA-CBG reimbursement on inpatient care of chronic renal disease is lower than the mean of hospital's medical care cost. Length of stay and doctors' compliance in using national medication formulation are important determinants to increase medical care cost. Hospital obtains profit from patients who upgrade type of class.
\end{abstract}

Keywords: care cost, INA-CBG reimbursement, chronic renal disease

\section{Correspondence:}

Mardhatillah. Kasih Ibu Hospital, Surakarta, Central Java.

Email: mardhatillah.bws@gmail.com. Mobile: 089510610891.

Mid-International Conference on Public Health, Best Western Premier Hotel, Solo, Indonesia, 18-19 April 2018 | 221 https://doi.org/10.26911/mid.icph.2018.04.01 